\title{
High Temperature Treatment of Selected Iron Rich Bauxite Ores to Produce Calcium Aluminate Slags ${ }^{\dagger}$
}

\author{
Adamantia Lazou ${ }^{1, *(\mathbb{D}}$, Casper van der Eijk ${ }^{2, *}{ }^{1}$, Michail Vafeias ${ }^{3}\left(\mathbb{D}\right.$, Amalia Bempelou $^{3}$,

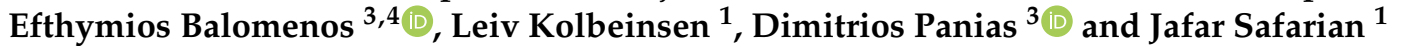

1 Department of Materials Science and Engineering, Norwegian University of Science and Technology, 7034 Trondheim, Norway; leiv.kolbeinsen@ntnu.no (L.K.); jafar.safarian@ntnu.no (J.S.)

2 SINTEF Industry, 7034 Trondheim, Norway

3 School of Mining and Metallurgical Engineering, National Technical University of Athens, 15780 Athens, Greece; michalisvafeias@mail.ntua.gr (M.V.); amaliampempelou@gmail.com (A.B.); thymis@metal.ntua.gr (E.B.); panias@metal.ntua.gr (D.P.)

4 Metallurgy Business Unit, Mytilineos S.A., 32003 Agios Nikolaos, Greece

* Correspondence: Adamantia.lazou@ntnu.no (A.L.); casper.eijk@sintef.no (C.v.d.E.)

+ Presented at International Conference on Raw Materials and Circular Economy, Athens, Greece, 5-9 September 2021.

Citation: Lazou, A.; van der Eijk, C.; Vafeias, M.; Bempelou, A.; Balomenos, E.; Kolbeinsen, L.; Panias, D.; Safarian, J. High Temperature Treatment of Selected Iron Rich Bauxite Ores to Produce Calcium Aluminate Slags. Mater. Proc. 2021, 5, 36. https:// doi.org/10.3390/materproc2021005036

Academic Editor: Anthimos Xenidis

Published: 30 November 2021

Publisher's Note: MDPI stays neutral with regard to jurisdictional claims in published maps and institutional affiliations.

Copyright: (c) 2021 by the authors. Licensee MDPI, Basel, Switzerland. This article is an open access article distributed under the terms and conditions of the Creative Commons Attribution (CC BY) license (https:/ / creativecommons.org/licenses/by/ $4.0 /)$.

\begin{abstract}
The Pedersen process is a method to produce alumina from Al-containing sources, and it is a more material-efficient method than the current commercial Bayer process, since the formation of bauxite residue (red mud) is avoided, and the bauxite can be holistically consumed. The smelting reduction (SR) part of the Pedersen process yields pig iron and a calcium aluminate slag, and the latter is a feedstock material for alumina extraction via alkaline leaching. In the present study, three different bauxite ores (Greek, Turkish and Jamaican) were smelted with lime to ease the process and control the slag chemistry and coke for the carbothermic reduction of iron oxides. The slags produced were analyzed with XRD, XRF, and EPMA to identify the phases and chemical compositions. According to the results, the slags composed of Al-containing leachable phases. Moreover, it is shown that the amount and distribution of both the leachable and non-leachable phases in the slags depend on the ore chemical composition. The results are discussed regarding the characteristics and potential leachability of the slags. Standard leaching tests were performed to examine the actual leachability.
\end{abstract}

Keywords: alumina production; Pedersen process; smelting-reduction; calcium aluminate slags; bauxite residue

\section{Introduction}

The Pedersen process is an alternative method for producing alumina. In this process, bauxite ore can be used, and the formation of bauxite residue (BR), which is a challenge in the commercial Bayer process, is avoided due to the extraction of iron in metallic form [1]. In the first step of the process, bauxite is mixed with lime as a flux and coke as reducing agent and then smelted and reduced. This step yields metallic iron and a calcium-aluminate slag as the main products. The calcium-aluminate slag is used for alumina extraction through alkaline leaching [2]. The most leachable calcium-aluminate phases are $12 \mathrm{CaO} \cdot 7 \mathrm{Al}_{2} \mathrm{O}_{3}$ $\left(\mathrm{C}_{12} \mathrm{~A}_{7}\right)$ and $\mathrm{CaO} \cdot \mathrm{Al}_{2} \mathrm{O}_{3}(\mathrm{CA})$ [2]. Another important phase in the slag is $\gamma-2 \mathrm{CaO} \cdot \mathrm{SiO}_{2}$ $\left(\gamma-C_{2} S\right)$, which is not only considered to be insoluble in the alkaline solution, but makes the slag self-disintegrate [3]. The self-disintegration is beneficial for reducing the cost of milling of the slag. This study was performed within the framework of the ENSUREAL project, which aims the production of iron and alumina by an integrated process flowsheet of a modernized Pedersen process and thus eliminating the production of BR.

In the present study, three different bauxites were used to investigate their potential use in the Pedersen process, which can use lower-grade materials. The bauxites were 
smelted, and the characteristics of the raw materials and the obtained slags were analyzed and discussed based on their potential applicability in the suggested process. The obtained results are also discussed with respect to theoretical predictions. Finally, the study includes standard leaching tests to provide a further insight in the actual leachability of the slags.

\section{Materials and Methods}

Three types of bauxite were tested: one bauxite sample supplied by Noranda, Jamaica, one bauxite sample was from Demireller Mining, Turkey, and one bauxite sample was supplied by MYTILINEOS S.A., Metallurgy Business, Greece. Moreover, a limestone quality that is a by-product (washing sands) obtained from OMYA, which is a leading global producer of industrial minerals, was tested because, this is of a quality that can be land-filled as of today. The raw materials (total ca. $2 \mathrm{~kg}$ ) were smelted in an open induction furnace. The amount of $\mathrm{CaO}$ was calculated based on mass balance and to obtain $\mathrm{C}_{12} \mathrm{~A}_{7}, \mathrm{C}_{2} \mathrm{~S}$ and $\mathrm{CaTiO}_{3}(\mathrm{CT})$ in the slags. The bauxite/quicklime/coke ratio (wt.\%) was set as 47.6/50 (limestone)/2.4,60.6/36.4/3.0,54.1/43.2/2.7 and 54/42/4.3 for the Jamaican, Turkish and Greek bauxite, respectively. The coking levels were set based on complete stochiometric reaction of all iron in the system according to $\mathrm{Fe}_{2} \mathrm{O}_{3}+3 \mathrm{C}=2 \mathrm{Fe}+3 \mathrm{CO}$. The bauxite, $\mathrm{CaO}$ and limestone were all crushed and sieved to a particle size below $4.5 \mathrm{~mm}$ and dried overnight before smelting. The materials were charged into a graphite crucible (inner diameter of $115 \mathrm{~mm}$ ) and heated in a 75-kVA open induction furnace to the target temperature with a gradient of $20-25^{\circ} \mathrm{C} / \mathrm{min}$ and kept at the target temperature for $1 \mathrm{~h}$. A slow cooldown was achieved by shutting off the furnace and leaving the crucible inside to reach room temperature.

The chemical composition of the raw materials and slags was measured with X-ray Fluorescence Spectrometer (XRF) and typical results are listed in Table 1. X-ray Diffraction (XRD) and Electron Probe Micro-Analyzer (EPMA), supported by Wavelength Dispersive Spectroscopy (WDS), were used for phase identification and microstructure observations, respectively. The XRD analysis was done using a Bruker D8-focus equipment with $\mathrm{CuK} \alpha$ radiation; for simplicity, only one typical slag analysis is presented here (Greek slag).

Table 1. Composition of the raw materials, measured by XRF, $\mathrm{wt}^{\mathrm{O}} \%$.

\begin{tabular}{|c|c|c|c|c|c|c|c|c|c|c|}
\hline \multirow[t]{2}{*}{ Oxides } & \multicolumn{3}{|c|}{ Bauxites } & \multicolumn{3}{|c|}{ Reagents } & \multicolumn{4}{|c|}{ Slags } \\
\hline & $\mathrm{J} * *$ & $T^{* *}$ & $\mathrm{G}^{* *}$ & Quicklime & Limestone & Coke & $\begin{array}{c}\mathrm{J}^{* *}+ \\
\text { Limestone }\end{array}$ & $\begin{array}{c}\mathrm{J}{ }^{*}+ \\
\text { Quicklime }\end{array}$ & $\begin{array}{c}\mathbf{T}^{* *}+ \\
\text { Quicklime }\end{array}$ & $\begin{array}{c}\mathrm{G}^{* *}+ \\
\text { Quicklime }\end{array}$ \\
\hline $\mathrm{Al}_{2} \mathrm{O}_{3}$ & 49.8 & 47.6 & 59.7 & 0.24 & 0.90 & 2.79 & 43.9 & 45.5 & 32.10 & 38.1 \\
\hline $\mathrm{SiO}_{2}$ & 1.3 & 15.7 & 2.5 & 0.46 & 1.73 & 0.47 & 3.00 & 1.70 & 8.31 & 3.89 \\
\hline $\mathrm{Fe}_{2} \mathrm{O}_{3}$ & 18.9 & 17.3 & 21.5 & 0.08 & 0.24 & 0.08 & 0.37 & 0.56 & 1.57 & 5.41 \\
\hline $\mathrm{TiO}_{2}$ & 2.5 & 6.45 & 2.7 & 0.02 & 0.03 & 0.095 & 2.00 & 1.72 & 7.31 & 2.12 \\
\hline $\mathrm{CaO}$ & 0.4 & 0.49 & 1.8 & 96.7 & 52.90 & 0.42 & 49.0 & 49.8 & 49.50 & 50.0 \\
\hline $\mathrm{MgO}$ & $<0.01$ & $<0.01$ & & 0.64 & 0.95 & 0.22 & 0.46 & 0.23 & 0.34 & 0.19 \\
\hline $\mathrm{V}_{2} \mathrm{O}_{5}$ & & & 0.1 & & & & & & 0.06 & 0.02 \\
\hline $\mathrm{Cr}_{2} \mathrm{O}_{3}$ & 0.12 & 0.12 & & & & & & & 0.08 & \\
\hline $\mathrm{K}_{2} \mathrm{O}$ & 0.03 & 0.22 & & & 0.09 & 0.18 & & & & \\
\hline $\mathrm{P}_{2} \mathrm{O}_{5}$ & 0.58 & 0.19 & & 0.02 & 0.01 & & & & $<0.01$ & \\
\hline $\mathrm{SrO}$ & 0.02 & 0.04 & & & 0.16 & & 0.23 & 0.05 & 0.04 & 0.03 \\
\hline $\mathrm{ZrO}_{2}$ & 0.09 & 0.04 & & & & & 0.08 & 0.08 & 0.05 & 0.02 \\
\hline $\mathrm{MnO}$ & & & & & & & & & 0.04 & \\
\hline S & & & 0.2 & & & & & & 0.09 & 0.15 \\
\hline LoI * & 25 & 11.6 & 11.5 & 0.5 & 42.80 & & & & & \\
\hline Fix C & & & & & & 87.68 & & & & \\
\hline
\end{tabular}

${ }^{*}$ Loss of Ignition. ** J: Jamaica, T: Turkey, G: Greece.

The slags were leached at National Technical University of Athens (NTUA). Standard leaching tests were performed in a stainless-steel reactor at $90{ }^{\circ} \mathrm{C}, 500 \mathrm{rpm}$ stirring rate, $120 \mathrm{~g} / \mathrm{L} \mathrm{Na}_{2} \mathrm{CO}_{3}$ and $10 \%$ pulp density under atmospheric pressure conditions. The reactor consists of the following interconnected units: (a) an electric Siemens motor for the stirrer, (b) a stirring control system, and (c) a receptor for the reactor vessel. The motor and stirring control system are the main electrical and mechanical parts of the reactor. The 
stirring rate is controlled manually with a stopcock located on the body of the reactor. The reactor vessel is made of stainless steel and has a total volume of $500 \mathrm{~mL}$, allowing the treatment of pulps with a volume of at least $400 \mathrm{~mL}$ and is secured on the reactor body with clamping rings. The reactor lid consists of two symmetrical, semicircular pieces of identical material. There is a gap between the outer side of the vessel and the inner side of the receptor that allows the circulation of thermal fluid, either for cooling or for heating. Fluid circulation is permitted by suitable fluid inlets and outlets located on the outside of the receptor. The temperature is controlled by a Huber thermal fluid circulator. Water is used as a heating and cooling fluid, as the operating temperatures are lower than the boiling point of water. Elemental chemical analysis of the aqueous solutions produced was performed in a PerkinElmer ${ }^{\mathrm{TM}}$ PinAAcle 900T Atomic Adsorption Spectrometer.

\section{Reduction and Slag-Phase Reactions}

Iron is expected to be completely reduced at the applied temperature $\left(1650^{\circ} \mathrm{C}\right)$. The most stable oxides, namely $\mathrm{Al}_{2} \mathrm{O}_{3}, \mathrm{CaO}$ etc., will be the main components of the slags. The slags are expected to be composed of $\mathrm{CaO}, \mathrm{Al}_{2} \mathrm{O}_{3}, \mathrm{SiO}_{2}$ and $\mathrm{TiO}_{2}$ based on the characteristics of the bauxites and the thermodynamic stability of these oxides in the studied conditions. Based on thermodynamic considerations and literature sources, expected slag phases might include perovskite (CT), $3 \mathrm{CaO} \cdot 2 \mathrm{TiO}_{2}\left(\mathrm{C}_{3} \mathrm{~T}_{2}\right), \mathrm{C}_{2} \mathrm{~S}, 2 \mathrm{CaO} \cdot \mathrm{Al}_{2} \mathrm{O}_{3} \cdot \mathrm{SiO}_{2}\left(\mathrm{C}_{2} \mathrm{AS}\right), \mathrm{C}_{12} \mathrm{Al}_{7}, \mathrm{CA}$, and $3 \mathrm{CaO} \cdot \mathrm{Al}_{2} \mathrm{O}_{3}\left(\mathrm{C}_{3} \mathrm{~A}\right)[4,5]$. With $\mathrm{C}_{3} \mathrm{~A}$ being less stable, it might react with $\mathrm{Al}_{2} \mathrm{O}_{3}$ and $\mathrm{SiO}_{2}$ to form $\mathrm{C}_{2} \mathrm{~S}$ and $\mathrm{C}_{12} \mathrm{Al}_{7}$ [5]. The lime additions were high enough, as mentioned, to avoid the formation of the $\mathrm{C}_{2} \mathrm{AS}$ as it will retard the alumina recovery. Nevertheless, this phase is thermodynamically stable and the possibility to be present in the slags is not excluded considering kinetic effects. As an example, a higher cooling rate than $20-25^{\circ} \mathrm{C} / \mathrm{min}$ might result in the formation of $C_{2} A S$ and $C_{3} A$ instead of $C_{12} A_{7}[6,7]$.

\section{Results}

The XRD results of the raw Greek bauxite indicate that diaspore $(\alpha-\mathrm{AlOOH})$ and boehmite $(\gamma-\mathrm{AlOOH})$ are the main Al-bearing minerals. Other phases were the hematite $\left(\mathrm{Fe}_{2} \mathrm{O}_{3}\right)$, anatase $\left(\mathrm{TiO}_{2}\right)$, calcite $\left(\mathrm{CaCO}_{3}\right)$ and kaolinite $\left(\mathrm{Al}_{2} \mathrm{Si}_{2} \mathrm{O}_{5}(\mathrm{OH})_{4}\right)$. The main Albearing minerals in the Turkish bauxite were kaolinite and diaspore, whereas in the Jamaican bauxite it was diaspore. The chemical compositions of the raw materials in Table 1 indicate higher $\mathrm{Si}$ content for the Turkish bauxite, confirming the predominance of kaolinite in it. In all cases, $\mathrm{Al}, \mathrm{Si}, \mathrm{Fe}$ and $\mathrm{Ti}$ were the main compounds, while the exact content was dependent on the characteristics and origin of the bauxites. The bauxite from Jamaica contains a lot of organic matter (high LoI). This makes it difficult to process this bauxite using the Bayer process. For the ENSUREAL process, the presence of extra carbon is not an issue. The high phosphor content of the Jamaican bauxite is another drawback, since phosphor will end up in the iron phase. This will decrease the market value of the iron. The bauxite from Turkey has much higher contents of Si and Ti than the bauxites from Greece and Jamaica. The higher Si content of the Turkish bauxite might retard the alumina extraction due to its co-dissolution. The Loss of Ignition content corresponds to material which will decompose upon smelting.

The composition of the slags is listed in Table 1. As expected, the slags were composed of $\mathrm{Ca}, \mathrm{Al}, \mathrm{Si}$ and Ti. The composition of the slag made from a mixture of Jamaican bauxite and quicklime is the cleanest Al-Ca-oxide slag with the lowest $\mathrm{Si}$ content. It is evident that the use of limestone washing sands instead of clean $\mathrm{CaO}$ has a significant influence on the $\mathrm{MgO}, \mathrm{SiO}_{2}$ and $\mathrm{TiO}_{2}$ of the Jamaican slag, and this might affect the leaching efficiency of the slag. The higher contents of $\mathrm{Si}$ and $\mathrm{Ti}$ in the Turkish slag implies that the recovery of $\mathrm{Al}_{2} \mathrm{O}_{3}$ might be lower than the rest of the slags. The pig iron from Jamaican bauxite was found to contain about $90.2 \% \mathrm{Fe}, 5.5 \% \mathrm{C}, 0.4 \% \mathrm{P}, 1.6 \% \mathrm{Ti}$, and $1.2 \% \mathrm{Mn}$.

EPMA analysis of the slag produced from the Jamaican bauxite and quicklime is shown in Figure 1a. The dominating phase in this slag is $\mathrm{C}_{12} \mathrm{~A}_{7}$, while the other phase (appears as darker grey) is $\mathrm{C}_{3} \mathrm{~A}$. The presence of $\mathrm{C}_{3} \mathrm{~A}$ might indicate a small surplus of $\mathrm{Ca}$ 
in the slag. Figure $1 \mathrm{~b}$ shows the structure of the of the slag produced from the Jamaican bauxite and limestone. $\mathrm{C}_{12} \mathrm{~A}_{7}$ is similarly the dominant phase (continuous grey phase). However, in this case, the second phase was found to have a higher content of Si which might be attributed to the $\mathrm{C}_{2} \mathrm{AS}$, indicating a small lack of $\mathrm{Ca}$. This also indicates that the addition of lime could be higher in the latter case due to the higher amount of Si from the limestone used. $\mathrm{C}_{2} \mathrm{AS}$ is an unwanted phase that is difficult to leach; $\mathrm{C}_{3} \mathrm{~A}$ is less leachable than $C_{12} A_{7}$. Nevertheless, in both cases, kinetic effects for the formation of $C_{3} A$ and $C_{2} A S$ cannot be excluded [7]. In both cases, the micro-crystalline bright phase is attributed to a Ca-Ti-O perovskite-like phase, which was found to contain some amount of Al.
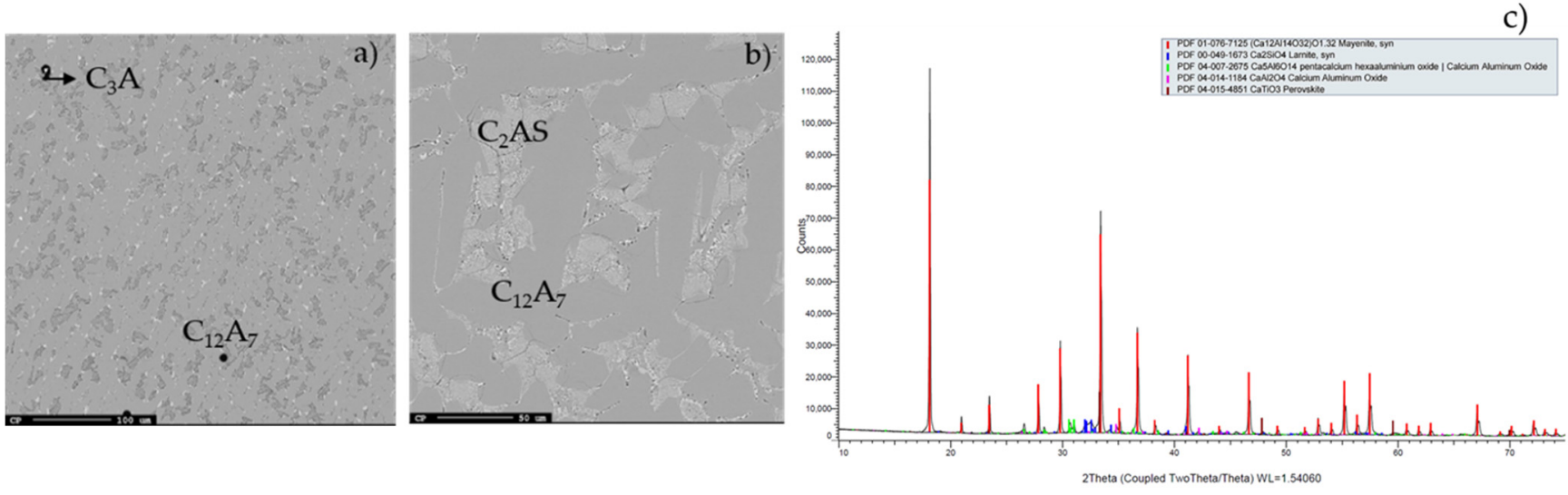

Figure 1. Micrographs of the slags produced from (a) Jamaican bauxite with quicklime, and (b) Jamaican bauxite with limestone. (c) XRD analysis of Greek slag.

Based on the XRD results, $C_{12} A_{7}$ was the dominant phase in the Greek slag, while $\mathrm{C}_{2} \mathrm{~S}$ and $\mathrm{C}_{5} \mathrm{~A}_{3}$ were also present, as seen in Figure 1c. As mentioned, slag produced from Jamaican bauxite with quicklime was composed of $C_{12} A_{7}$ and $C_{3} A$, while $C T$ and $C_{5} A_{3}$ were also detected. The Turkish bauxite was mainly composed of $C_{5} A_{3}, C T$ and $C_{2} S$ in two modifications (larnite and calcio-olivine). The chemical composition of $\mathrm{C}_{5} \mathrm{~A}_{3}$ phase is very similar to $\mathrm{C}_{12} \mathrm{~A}_{7}$, and a similar extraction behavior is expected. The slag is, however, a much harder and more complex material than the Greek slag. This might be due to the presence of $\mathrm{CT}$ in relatively high concentration and the complex structure.

Results of the standard leaching tests are shown in Table 2.

Table 2. Results of standard leaching tests performed on slags.

\begin{tabular}{ccccc}
\hline Slags & $\begin{array}{c}\text { Al Extraction Yield } \\
\text { (PLS + Washing } \\
\text { Solutions) }\end{array}$ & $\begin{array}{c}\mathbf{A l}_{2} \mathbf{O}_{3} \text { Concentration } \\
\text { (g/L) (PLS) }\end{array}$ & $\begin{array}{c}\text { Mean Si Extraction } \\
\text { Yield (PLS + Washing } \\
\text { Solutions) }\end{array}$ & $\begin{array}{c}\text { SiO }_{2} \text { Concentration } \\
\text { (g/L) (PLS) }\end{array}$ \\
\hline $\mathrm{J}^{* *}+$ Limestone & $54.7 \%$ & 22.0 & $19.2 \%$ & 0.64 \\
$\mathrm{~J}^{* *}+$ Quicklime & $59.7 \%$ & 25.0 & $37.9 \%$ & 0.58 \\
$\mathrm{~T}^{* *}+$ Quicklime & $42.3 \%$ & 12.72 & $3.8 \%$ & 0.28 \\
$\mathrm{G}^{* *}+$ Quicklime & $55.0 \%$ & 19.41 & $14.1 \%$ & 0.51 \\
\hline
\end{tabular}

** J: Jamaica, T: Turkey, G: Greece.

\section{Discussion}

The smelting reduction of the bauxite sources is suitable for separating iron in metallic iron and calcium aluminate slag, based on the obtained results. This shows that iron can be recovered and further used if the characteristics are appropriate, which, to a large extent, will depend on the characteristics of the raw materials used and the smelting conditions. According to the analysis of the Jamaican pig iron, a refining process might be necessary to reduce the $\mathrm{P}$ level before any processing. Nevertheless, the potential uses and justification 
of the specific characteristics may require further investigations that are not within the scope of the present study.

The leaching efficiency will depend on the characteristics of the slags. Based on an earlier work, calcium aluminate slag with $\mathrm{SiO}_{2}$ of about $4.6 \%$ resulted in high alumina recoveries $(94.4 \%)$, while a decrease was seen for higher $\mathrm{SiO}_{2}$ [8]. According to the theoretical basis and the obtained results, the slags were composed mainly of phases that are considered leachable. Nevertheless, leaching of $\mathrm{Al}_{2} \mathrm{O}_{3}$ from calcium aluminate slags proved to be more complex than the theoretical expectations suggested. The slags have different chemical characteristics (different levels of $\mathrm{Ca}, \mathrm{Al}, \mathrm{Si}$ ) due to the different characteristics of the raw bauxites (Table 1). As an example, the higher contents of Si and Ti in the Turkish bauxite is reflected in the higher contents of these elements in the slag. This was expected on the basis of the mineralogical phases obtained through XRD analysis, whereby the contents of $\mathrm{C}_{2} \mathrm{~S}$ and $\mathrm{CT}$ in Turkish slag were higher than in the other slags. The $\mathrm{C}_{2} \mathrm{~S}$ phase was seen in two modifications, which might indicate non-uniform cooling during solidification. The formation of $\mathrm{CT}$ and $\mathrm{C}_{2} \mathrm{~S}$ was expected due to their thermodynamic stability in the studied conditions. The CT phase is believed not to affect alumina recovery [3], as long as it is stoichiometric. Otherwise, it might incorporate $\mathrm{Al}$ in its structure [9] and reduce $\mathrm{Al}$ recovery. The leachability is highly dependent on the crystallization path of the slags and the area of primary precipitation [8]. The slags need to be properly controlled within the ternary phase composition of $\mathrm{C}_{12} \mathrm{~A}_{7}, \mathrm{C}_{2} \mathrm{~S}$ and $\mathrm{CA}$. Slags that are closer to the $\mathrm{C}_{3} \mathrm{~A}$ boundary line, such as those produced from Jamaican bauxite, are expected to result in lower $\mathrm{Al}$ recoveries. The co-dissolution of $\mathrm{Si}$ is a major challenge, and a pre-desilication step is necessary to achieve the $\mathrm{Si}$ requirements in the alumina.

The $\mathrm{C}_{12} \mathrm{~A}_{7}$ was expected to be the main calcium aluminate phase, which is the most leachable compound, and this was confirmed for the Jamaican and Greek slags. A deviation from this trend was seen for the Turkish bauxite, in which the main calcium aluminate phase was $C_{5} A_{3}$. $C_{5} A_{3}$ is formed instead of $C_{12} A_{7}$ in the absence of moisture [10]. The presence of this phase was not expected, since the experiments were performed in an open induction furnace, where the presence of humidity from the atmosphere can be assumed. Other stabilizing agents for the $\mathrm{C}_{12} \mathrm{~A}_{7}$ phase are reported to be, among others, $\mathrm{C}, \mathrm{S}$, and $\mathrm{SiO}_{2}$ [11-13]. However, none of these agents seem to stabilize the $\mathrm{C}_{12} \mathrm{~A}_{7}$ phase in the Turkish slag, and it would be of future interest to justify the exact reason for this deviation. Nevertheless, the $\mathrm{C}_{5} \mathrm{~A}_{3}$ phase is reported to be leachable, and theoretically will not retard the alumina recovery [8]. Although the results seem promising and leachable phases can be achieved, further research is required to optimize the application of the materials in the Pedersen process, as further process steps might be necessary to achieve high-purity products, especially for the Turkish bauxite.

The results of the standard leaching tests do not seem to confirm the initial estimations, as Jamaican bauxite slags show significantly higher $\mathrm{Al}$ recoveries and despite the small percentage of $\mathrm{SiO}_{2}$ content, its co-dissolution is particularly high. On the contrary, the recovery of $\mathrm{Si}$ in the Turkish slag is in the expected range, while the recovery rates of $\mathrm{Al}$ remain low $(\sim 42 \%)$. A striking difference between Greek bauxite slags and Jamaican bauxite slags is the high Si extraction observed for the latter (\% Si yields > 20\%). Greek bauxite slags consistently reached $\%$ Si yields $\approx 12-15 \%$ and similar $\mathrm{Al}$ recoveries ( $\approx 55 \%$ ).

Funding: This project has received funding from the European Union's Horizon 2020 research and innovation programme under grant agreement No. 767533.

Institutional Review Board Statement: Not applicable.

Informed Consent Statement: Not applicable.

Data Availability Statement: Some of the data presented in this study are openly available in Zenodo at [10.5281/ZENODO.4587443], reference number [14-16]. Further data that support the findings of this study are available online upon request from the authors, A.L., C.v.d.E. and M.V.

Conflicts of Interest: The authors declare no conflict of interest. 


\section{References}

1. Safarian, J.; Kolbeinsen, L. Sustainability in alumina production from bauxite. In Sustainable Industrial Processing Summit; FLOGEN Star Outreach: Montreal, QC, Canada, 2016; pp. 75-82.

2. Miller, J.; Irgens, A. Alumina Production by the Pedersen Process-History and Future. In Essential Readings in Light Metals: Volume 1 Alumina and Bauxite; Donaldson, D., Raahauge, B.E., Eds.; Springer International Publishing: Cham, Switzerland, 1974; pp. 977-982.

3. Fursman, O.; Blake, H.; Mauser, J. Recovery of Alumina and Iron from Pacific Northwest Bauxites by the Pedersen Process; US Department of the Interior, Bureau of Mines: Washington, DC, USA, 1968; pp. 1-24.

4. Azof, F.I.; Kolbeinsen, L.; Safarian, J. Characteristics of Calcium-Aluminate Slags and Pig Iron Produced from Smelting-Reduction of Low-Grade Bauxites. Metall. Mater. Trans. B 2018, 49, 2400-2420. [CrossRef]

5. Zhang, Y.Y.; Lü, W.; Qi, Y.H.; Zou, Z.S. Recovery of iron and calcium aluminate slag from high-ferrous bauxite by high-temperature reduction and smelting process. Int. J. Miner. Metall. Mater. 2016, 23, 881-890. [CrossRef]

6. Lazou, A.; Van Der Eijk, C.; Tang, K.; Balomenos, E.; Kolbeinsen, L.; Safarian, J. The Utilization of Bauxite Residue with a Calcite-Rich Bauxite Ore in the Pedersen Process for Iron and Alumina Extraction. Metall. Mater. Trans. B 2021, 52, $1255-1266$. [CrossRef]

7. Wang, B.; Sun, H.; Zhang, X.; Bi, S. The Effect of Cooling Rate on the Leachability of Calcium Aluminate Slags. In Light Metals 2011; John Wiley \& Sons, Inc.: Hoboken, NJ, USA, 2011; pp. 241-244.

8. Hignett, T.P. Production of Alumina from Clay by a Modified Pedersen Process A lime-sinter modification of the Pedersen process for producing alumina from clay was investigated through operation of a pilot plant with a capacity of 300 pounds of alumina. Ind. Eng. Chem. 1947, 39, 1052-1060. [CrossRef]

9. Jacob, K.T.; Rajitha, G. Gibbs energy of formation of $\mathrm{Ca}_{3} \mathrm{Ti}_{8} \mathrm{Al}_{12} \mathrm{O}_{37}$ and phase relations and chemical potentials in the system $\mathrm{Al}_{2} \mathrm{O}_{3}-\mathrm{TiO}_{2}$-CaO. J. Phase Equilibria Diffus. 2012, 33, 293-302. [CrossRef]

10. Nurse, R.; Welch, J.H.; Majumdar, A.J. The $12 \mathrm{CaO} \cdot 7 \mathrm{Al}_{2} \mathrm{O}_{3}$ phase in the $\mathrm{CaO}-\mathrm{Al}_{2} \mathrm{O}_{3}$ system. Trans. Nonferrous Met. Soc. China 1965, 44, 323-332.

11. Kim, S.J.; Kageyama, M.; Gao, X.; Ueda, S.; Kitamura, S.Y. Solubility of Sulfur in the Solid Oxide of the Calcium-Aluminate System. ISIJ Int. 2019, 59, 1752-1755. [CrossRef]

12. Kim, S.W.; Hosono, H. Philosophical Magazine Synthesis and properties of $12 \mathrm{CaO} \cdot 7 \mathrm{Al}_{2} \mathrm{O}_{3}$ electride: Review of single crystal and thin film growth. Philos. Mag. 2012, 92, 2596-2628. [CrossRef]

13. Azof, F.I.; Tang, K.; You, J.; Safarian, J. Synthesis and Characterization of $12 \mathrm{CaO} \cdot 7 \mathrm{Al}_{2} \mathrm{O}_{3}$ Slags: The Effects of Impurities and Atmospheres on the Phase Relations. Metall. Mater. Trans. B 2020, 51, 2689-2710. [CrossRef]

14. van der Eijk, C. Time-Temperature: Bauxite Jamaica and CaO. 2021. Available online: https://zenodo.org/record/4587443\# .YaWIarq-uUk (accessed on 10 November 2021).

15. van der Eijk, C. Time-Temperature: Bauxite from Jamaica and Limestone. 2021. Available online: https://zenodo.org/record/45 87441 (accessed on 10 November 2021).

16. van der Eijk, C. Time-Temperature: Bauxite from Turkey and CaO. 2021. Available online: https://zenodo.org/record/4587448\# .YaWJobq-uUk (accessed on 10 November 2021). 